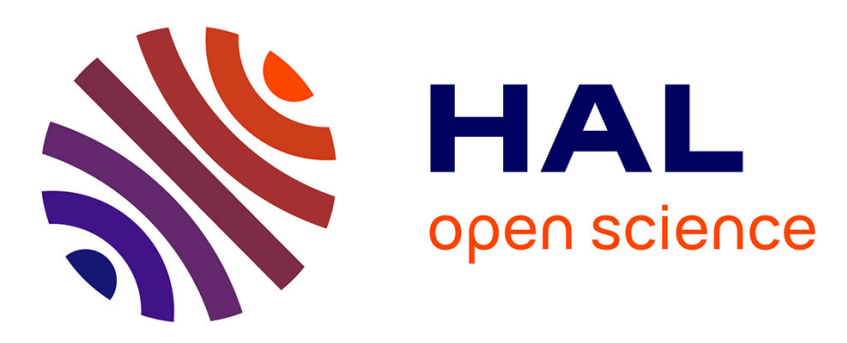

\title{
Expedient synthesis of NOxy-Heterocyclic Carbenes (NOHC) ligands and metal complexes using mechanochemistry
}

Aneta Wróblewska, Gaëtan Lauriol, Grzegorz Mlostoń, Xavier Bantreil, Frédéric Lamaty

\section{To cite this version:}

Aneta Wróblewska, Gaëtan Lauriol, Grzegorz Mlostoń, Xavier Bantreil, Frédéric Lamaty. Expedient synthesis of NOxy-Heterocyclic Carbenes (NOHC) ligands and metal complexes using mechanochemistry. Journal of Organometallic Chemistry, 2021, 949, pp.121914. 10.1016/j.jorganchem.2021.121914 . hal-03324425

\section{HAL Id: hal-03324425 \\ https://hal.science/hal-03324425}

Submitted on 24 Aug 2021

HAL is a multi-disciplinary open access archive for the deposit and dissemination of scientific research documents, whether they are published or not. The documents may come from teaching and research institutions in France or abroad, or from public or private research centers.
L'archive ouverte pluridisciplinaire HAL, est destinée au dépôt et à la diffusion de documents scientifiques de niveau recherche, publiés ou non, émanant des établissements d'enseignement et de recherche français ou étrangers, des laboratoires publics ou privés. 


\title{
Expedient synthesis of $\mathrm{N}-\mathrm{Oxy}$-Heterocyclic Carbenes (NOHC) ligands and metal complexes using mechanochemistry
}

\author{
Aneta Wróblewska ${ }^{\mathrm{a}, *}$, Gaëtan Lauriol ${ }^{\mathrm{c}}$, Grzegorz Mlostoń ${ }^{\mathrm{b}}$, Xavier Bantreil ${ }^{\mathrm{c}}$, \\ Frédéric Lamaty ${ }^{\mathrm{c}, *}$ \\ ${ }^{a}$ Centre of Molecular and Macromolecular Studies, Polish Academy of Sciences, Sienkiewicza 112, 90-363 Lodz, Poland \\ ${ }^{\mathrm{b}}$ Department of Organic and Applied Chemistry, University of Lodz, Tamka 12, 91-403 Lodz, Poland \\ ' IBMM, Univ Montpellier, CNRS, ENSCM, Montpellier, France
}

\begin{abstract}
A B S T R A C T
1,3-Di(benzyloxy)imidazol-2-ylidenes (or NOHCs) possess structures related to $N$-heterocyclic carbenes (NHCs), with potentially useful applications including the stabilization of metals. In order to prepare NOHC metal complexes, a multi-step synthesis involving mechanochemistry, and making use of ballmilling, was designed. A library of unprecedented NHOC metal complexes were tested for their cytotoxic activities against HCT116 colorectal cancer cell line. The tests demonstrated that the studied complexes displayed a similar activity, comparable with that one exhibited by the ligand. However, a remarkable activity was found in the case of silver complex 5 with an $\mathrm{IC}_{50}$ value of $0.75 \mu \mathrm{M}$, comparable to that of doxorubicin.
\end{abstract}

\section{Introduction}

Mechanochemistry, defined as the use of mechanical forces to synthesize or degrade molecules, is currently recognized as an innovative technology that can facilitate the practical and sustainable preparation of both organic and inorganic compounds [1]. This approach, possibly involving mechanical milling, with the use of ball-mills, enables the development of solvent-free syntheses in a very efficient way $[2,3]$. Along with organic molecules, synthesized mechanochemically, ligands and discrete metal complexes have a place of choice since many advantages of this solid-state synthesis have found a direct illustration in this area [4-7]. It is worth citing (i) shorter reaction time (ii) elimination or significant decrease of the amount of reaction solvent (iii) facilitated purification resulting from more easily attained reaction completion. In most cases, metallic complexes are isolated by crystallization, and the combination of mechanosynthesis with this recovery technique makes it a very powerful methodology, useful in organic and organometallic chemistry as well.

$\mathrm{N}$-heterocyclic carbenes (NHC) and their corresponding complexes have found an essential place in the area of coordination

\footnotetext{
Dedicated to Prof. Elena Shubina on the occasion of her 70th birthday

* Corresponding author.

E-mail addresses: frederic.lamaty@umontpellier.fr (F. Lamaty).
}

chemistry. Since the discovery of 1,2-bis(adamantan-1-yl)imidazol2 -ylidene as a stable, crystalline compound, [8,9] the poor reputation about nucleophilic carbenes as laboratory curiosities changed dramatically and nowadays nucleophilic carbenes are recognized as useful substrates with diverse applications in catalysis (metallic and organic), [10-13] in material science [14] and biology [15,16]. In recent years, it has been shown that the mechanosynthesis of ligands and corresponding NHC complexes offers a very efficient approach to the target compounds (Scheme 1) [17-30]. Various types of NHC ligands could be prepared or employed, together with a wide range of metals such as $\mathrm{Ag}, \mathrm{Cu}, \mathrm{Au}, \mathrm{Pt}, \mathrm{Ru}, \mathrm{Pd}$, to prepare a new collection of organometallics. Of note, in general, the process is faster, cleaner, and, even, in some cases, providing products difficult or impossible to obtain via a solution synthesis. In recent years, numerous mechanosynthesized NHC complexes found attractive applications in catalysis $[25,30,31]$ and medicinal chemistry [27].

4-Hydroxyl-imidazole 3-oxides and imidazolium salts derived therefrom constitute a group of heterocyclic compounds related to the NHCs since they can be considered as precursors of their oxyanalogues (NOHCs). Efficient methods for their preparation have been reported in recent decades, [32-35] but so far, the number of applications is rather limited. One can cite their usage as ionic liquids (in the form of corresponding imidazolium salt), [36-42] for biological applications, [43] as ligands for complexation of metals, [44-48] as additives in reactions $[49,50]$ or as unique building 
Previous work<smiles>[R]C(=O)C([R])=NO</smiles>

Scheme 1. Mechanosynthesis of metalated NHCs and outline of the current work (vbm= vibratory ball mill).

blocks for the preparation of some co-crystals [51,52]. In our continuing studies on the preparation of this class of imidazole derivatives and owing to the success of the mechanochemical strategy for the preparation of NHCs, we decided to explore the mechanosynthesis of NOHCs and corresponding metal complexes, using a vibratory ball mill (vbm) (Scheme 1). In addition, another goal of the present study was the evaluation of the cytotoxicity of some of NOHCs and their complexes on the colorectal HCT116 cell line.

\section{Results and discussion}

\subsection{Mechanosynthesis of NOHC ligands and metal-complexes}

In a series of our recent papers, synthesis and reactivity of symmetric and non-symmetric di(alkyloxy)imidazol-2-ylidines have been described $[43,53,54]$. In solution, three efficient methods are reported for the preparation of 1,3-dialkoxy imidazolium salts 2 which are applied as precursors of NOHCs derived from imidazole [55]. The first synthetic approach is based on the initial preparation of 2-unsubstituted 1 -alkoxy imidazole $\mathrm{N}$-oxides, followed by $O$-alkylation by treatment with benzyl bromide or benzyl chloride as typical alkylating reagents [49]. The second method is based on a three component reaction between glyoxal, corresponding $\mathrm{N}$-alkoxyamine, e.g. adamantyl-1-oxyamine, and formaldehyde in the presence of a strong BrØnsted acid[56]. Finally, the third strategy comprises double $O$-alkylation of 1 hydroxyimidazole 3-oxides $\mathbf{1}$, prepared initially from a diketone, hydroxylamine, and formaldehyde [55]. This latter method (Scheme 1) was selected for the development of the mechanosynthesis of 1,3-di(alkyloxy)imidazolium salts 2 , and subsequent preparation of corresponding 1,3-di(alkyloxy)imidazole-2-ylidenes metal complexes, including metals, such as $\mathrm{Ag}, \mathrm{Cu}$ and $\mathrm{Au}$.

The synthesis of starting 1-hydroxyimidazole $N$-oxides $\mathbf{1 a - c}$ was carried out based on the method presented in Scheme 1. Inspired by the synthesis performed in solution, [49] corresponding diketone and hydroxylamine were mixed in a vibratory ball mill (vbm) for $1 \mathrm{~h}$. Paraformaldehyde and a small amount of $36 \% \mathrm{HCl}_{\mathrm{aq}}$. used together as the acid catalyst and additive for Liquid Assisted Grinding, [57-59] were added to the milling jar and mixed for another $1 \mathrm{~h}$. Recovery of the reaction mixture and adjustment of the $\mathrm{pH}$, as performed in classical solution synthesis, proved to be inefficient for isolation of the expected product. However, switching from 36\% $\mathrm{HCl}_{\mathrm{aq}}$. to acetic acid gave much better results. It has to be noted that the grinding could not be carried out in a stainless-steel jar because of its degradation resulting from the acidity of the reac- tion medium. Instead, agate or zirconia-made jars and balls were preferred to develop an efficient procedure. Next, the crude reaction mixture was treated with aqueous ammonia and after separation of ammonium acetate, the products were purified by column chromatography. Compared to the synthesis in solution, the reaction was faster when performed in a ball mill (two times $1 \mathrm{~h}$ vs $20 \mathrm{~h}$ ). Imidazole $N$-oxides $1 \mathrm{a}-\mathrm{c}$ were isolated as colorless solids and their structures were confirmed by spectroscopic analyses. In the case of 1a, two ${ }^{1} \mathrm{H}$ NMR signals found at $7.09 \mathrm{ppm}$ and $8.30 \mathrm{ppm}$ were attributed to two equivalent $\mathrm{H}$ atoms, $\mathrm{H}(4)$ and $\mathrm{H}(5)$, and to $\mathrm{H}(2)$ atom, respectivelv (see SupDorting Information). The ${ }^{1} \mathrm{H}$ NMR spectrun

located at 2.10 (2 Me groups

the $\mathrm{H}(2)$ signal of 1c was found as a singlet located at $8.01 \mathrm{ppm}$ along with signals of aromatic $\mathrm{C}-\mathrm{H}$ atoms found in the region 7.29-7.44 ppm.

Treatment of the starting $\mathrm{N}$-oxides 1a-c with a variety of methyl-substituted benzyl bromides in the presence of a base and $\mathrm{MeOH}$ as a liquid assistant to provide 1,3di(benzyloxy)imidazolium salts $\mathbf{2}$ was also performed in a vibratory ball mill. The use of a base was necessary to remove the proton from the hydroxyl group located at $\mathrm{N}(1)$ of the imidazole ring. Among diverse bases $\left(\mathrm{Cs}_{2} \mathrm{CO}_{3}, \mathrm{~K}_{2} \mathrm{CO}_{3}, \mathrm{Na}_{2} \mathrm{CO}_{3}, \mathrm{NaHCO}_{3}\right)$, which were tested during the optimization process of this reaction, the best results were achieved using $\mathrm{Cs}_{2} \mathrm{CO}_{3}$. In the case of $\mathbf{1 a}$ and $\mathbf{1 b}$, benzylation led smoothly to the expected imidazole salts $\mathbf{2 a - h}$ (Scheme 2). However, attempted benzylations of $\mathrm{N}$-oxides 1c was unsuccessful and, in all cases, led to a complex mixture of unidentified products. Very likely, the unsatisfactory course of this reaction resulted from the steric hindrance provided by the phenyl rings at $C(4)$ and $C(5)$ positions. Products 2a-h were purified by filtration through a plug of celite. Here again, the mechanochemical approach offered an advantageous solvent-free procedure, with shorter reaction times $(30 \mathrm{~min})$ compared to experiments performed in solution (24-48 h).

The imidazolium salts 2 were soluble in organic solvents such as $\mathrm{MeOH}, \mathrm{CH}_{2} \mathrm{Cl}_{2}, \mathrm{CHCl}_{3}$, and the NMR spectra run in $\mathrm{CDCl}_{3}$ solutions confirmed the symmetric structure of the studied molecules. For example, in the case of $\mathbf{2 a}$, a characteristic signal of $\mathrm{C}(2) \mathrm{H}$ was down-field shifted compared to 1a and appeared at $10.98 \mathrm{ppm}$ and the signals of two equivalent $\mathrm{CH}_{2}$ groups were found as a singlet at $5.53 \mathrm{ppm}$. In the ${ }^{13} \mathrm{C}$ NMR spectra, one signal located at $117.8 \mathrm{ppm}$ was attributed to two equivalent $C(4)$ and $C(5)$ atoms of the imidazole ring. The symmetric structure of all imidazolium salts $\mathbf{2} \mathbf{b}-\mathbf{h}$ was confirmed by analogous ${ }^{1} \mathrm{H}$ and ${ }^{13} \mathrm{C}$ NMR data. 


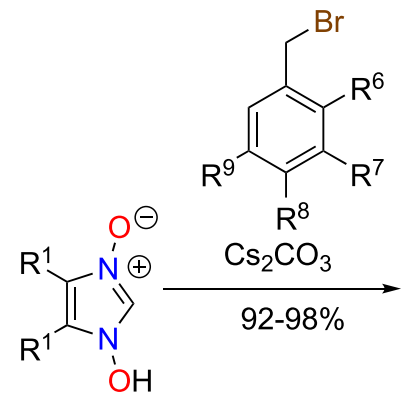

1a-c

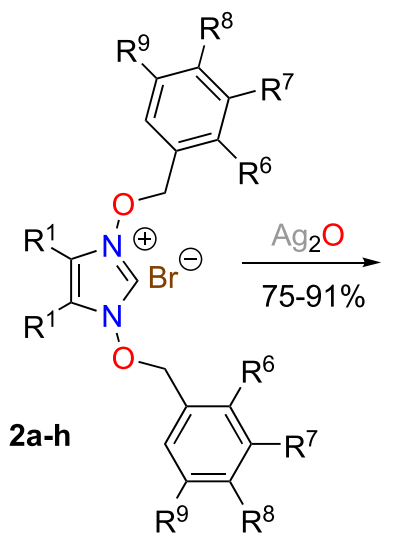<smiles>[R]C1=C([R])N(OCc2cc([R9])c([R7])c([R7])c2[R7])C([Al]Br)N1OCc1cc([R])c([R7])c([R])c1[R7]</smiles>

\begin{tabular}{llc}
\cline { 2 - 3 } $\mathbf{1}$ & $\mathrm{R}^{1}$ & Yield (\%) \\
\hline $\mathrm{a}$ & $\mathrm{H}$ & 69 \\
$\mathrm{~b}$ & $\mathrm{Me}$ & 89 \\
$\mathrm{c}$ & $\mathrm{Ph}$ & 56
\end{tabular}

\begin{tabular}{llllllcc}
\cline { 2 - 7 } 2, 3 & $\mathrm{R}^{1}$ & $\mathrm{R}^{6}$ & $\mathrm{R}^{7}$ & $\mathrm{R}^{8}$ & $\mathrm{R}^{9}$ & $\begin{array}{c}\text { Yield of 2 } \\
\text { (\%) }\end{array}$ & $\begin{array}{c}\text { Yield of 3 } \\
(\%)\end{array}$ \\
\hline $\mathrm{a}$ & $\mathrm{H}$ & $\mathrm{H}$ & $\mathrm{H}$ & $\mathrm{H}$ & $\mathrm{H}$ & 92 & 76 \\
$\mathrm{~b}$ & $\mathrm{H}$ & $\mathrm{H}$ & $\mathrm{Me}$ & $\mathrm{H}$ & $\mathrm{Me}$ & 98 & 91 \\
$\mathrm{c}$ & $\mathrm{H}$ & $\mathrm{H}$ & $\mathrm{H}$ & $\mathrm{Me}$ & $\mathrm{H}$ & 94 & 84 \\
$\mathrm{~d}$ & $\mathrm{H}$ & $\mathrm{Me}$ & $\mathrm{H}$ & $\mathrm{H}$ & $\mathrm{H}$ & 97 & 75 \\
$\mathrm{e}$ & $\mathrm{Me}$ & $\mathrm{H}$ & $\mathrm{H}$ & $\mathrm{H}$ & $\mathrm{H}$ & 93 & 86 \\
$\mathrm{f}$ & $\mathrm{Me}$ & $\mathrm{H}$ & $\mathrm{Me}$ & $\mathrm{H}$ & $\mathrm{Me}$ & 98 & 89 \\
$\mathrm{~g}$ & $\mathrm{Me}$ & $\mathrm{H}$ & $\mathrm{H}$ & $\mathrm{Me}$ & $\mathrm{H}$ & 97 & 85 \\
$\mathrm{~h}$ & $\mathrm{Me}$ & $\mathrm{Me}$ & $\mathrm{H}$ & $\mathrm{H}$ & $\mathrm{H}$ & 97 & 77 \\
\hline
\end{tabular}

Scheme 2. Synthesis of 1,3-(dibenzyloxy)imidazolium bromides 2 and NOHC silver complexes 3.

The next step of this study consisted in the preparation of NOHC metal complexes. Since silver complexes are recommended as entry materials to prepare other metalated products via transmetalation protocol, the mechanosynthesis of Ag complexes of the studied NOHCs 2 was next performed. It is known that NHC-silver complexes can easily be prepared in solution [60] or alternatively in a ball mill $[18,19,21,27]$ by reaction of an imidazolium salt with $\mathrm{Ag}_{2} \mathrm{O}$. The previously optimized ball mill procedure was thus applied starting with a 1:0.5 mixture of a corresponding bis-alkylated imidazolium oxide salt 2 and $\mathrm{Ag}_{2} \mathrm{O}$, reacted neat in a milling jar agitated at $25 \mathrm{~Hz}$.

In all cases, the experiment was finished after $30 \mathrm{~min}$, and the desired complexes were isolated as pale yellow or colorless solids (Scheme 2). This procedure was applied successfully to precursors 2a-h and actually, this is the first synthesis of monodentate 1,3di(benzyloxy)imidazol-2-ylidene silver complexes. In the representative case of symmetric salt $\mathbf{2 e}$, the isolated complex $\mathbf{3 e}$ was characterized spectroscopically, showing in the ${ }^{1} \mathrm{H}$ NMR spectrum two characteristic singlets located at 1.85 and $5.28 \mathrm{ppm}$ corresponding to two equivalent Me and two equivalent benzylic $\mathrm{CH}_{2}$ units, respectively. In the ${ }^{13} \mathrm{C}$ NMR, the corresponding signals were found at 7.7 and $82.2 \mathrm{ppm}$, respectively. In addition, the absence of the $\mathrm{C}(2) \mathrm{H}$ signal of the imidazole ring at ca. $11.72 \mathrm{ppm}$ confirmed the elimination of the $\mathrm{H}$-atom and the formation of the expected carbenic center. Apparently, the observed down-field shift of the signals attributed to the $\mathrm{CH}_{2}$ groups results from the presence of oxygen atoms forming the $\mathrm{N}-\mathrm{O}$ bond. The most characteristic $\mathrm{C}(2)-$ atom forming the carbenic center absorbed at $166.5 \mathrm{ppm}$. Similarly, the signals of the $C(2)$ atoms in other complexes 3 were found in the region between 165.6-170.6 ppm. HRMS confirmed molecular formulas of complexes 3 with peaks corresponding to the [M$\left.\mathrm{Br}^{-}\right]^{+}$ion.
Since, as reported earlier, NHC-homoleptic silver complexes were also synthesized mechanochemically, [19,27] starting with an imidazolium salt and $\mathrm{Ag}_{2} \mathrm{O}$, we also decided to apply this approach for the preparation of NOHCs silver analogues. The first step consisted in introducing a less coordinating anion by ball milling $\mathbf{2 f}$ with $\mathrm{KPF}_{6}$, and the anion metathesis provided the desired imidazolium 4 in $90 \%$ yield. Gratifyingly, grinding of imidazolium hexafluorophosphate salt 4 with 2 equivalents of $\mathrm{Ag}_{2} \mathrm{O}$ furnished complex 5 in $87 \%$ yield after $4 \mathrm{~h}$ (Scheme 3).

The same product was also obtained in a one-jar stepwise procedure which involves anion exchange $\mathrm{Br}^{-} \rightarrow \mathrm{PF}_{6}{ }^{-}$as an initial step, achieved by 30 min of grinding bromide $2 \mathbf{f}$ with an equimolar amount of $\mathrm{KPF}_{6}$. Subsequent addition of $\mathrm{Ag}_{2} \mathrm{O}$ and further grinding for $1 \mathrm{~h}$ led to a black powder. Filtration through a celite layer and evaporation of the solvent delivered the desired complex $\mathbf{5}$ in $80 \%$ yield (Scheme 3 ). It is worth mentioning that only a single example of such complexes, synthesized exclusively in solution, has yet been reported [47]. However, a longer reaction time (24 h) was required to complete the complexation reaction.

In analogy to complexes 3f, signals of two equivalent Me groups appeared in ${ }^{1} \mathrm{H}$ NMR as a singlet found at $6.93 \mathrm{ppm}$ along with four equivalent $\mathrm{CH}_{2}$ benzyl groups located at $5.06 \mathrm{ppm}$. The molecular mass $M=835.3352\left[{\mathrm{M}-\mathrm{PF}_{6}}^{-}\right]^{+}$was confirmed by HRMS. Of note, all Ag-complexes $\mathbf{3}$ and $\mathbf{5}$ were light-sensitive substances that underwent a slow decomposition during the storage and for that reason, they had to be stored in the dark.

Anticipated structures of $\mathbf{2 f}$ and $\mathbf{5}$ were unambiguously confirmed by single crystal X-ray diffraction analysis. The structure of 5 (Fig. 1a) was compared to the structure of cationic $\left[\mathrm{Ag}(\mathbf{2} \mathbf{f})_{2}\right] \mathrm{PF}_{6}$ complex 6, reported in the literature [47] (Fig. 1b).

Firstly, compared to imidazolium salt $\mathbf{2 f}$, the N-C-N angles in silver carbene $\mathbf{5}$ are smaller (104.4 in $\mathbf{2 a}$ vs $99.8^{\circ} / 100.5^{\circ}$ in $\mathbf{5}$ ).This 


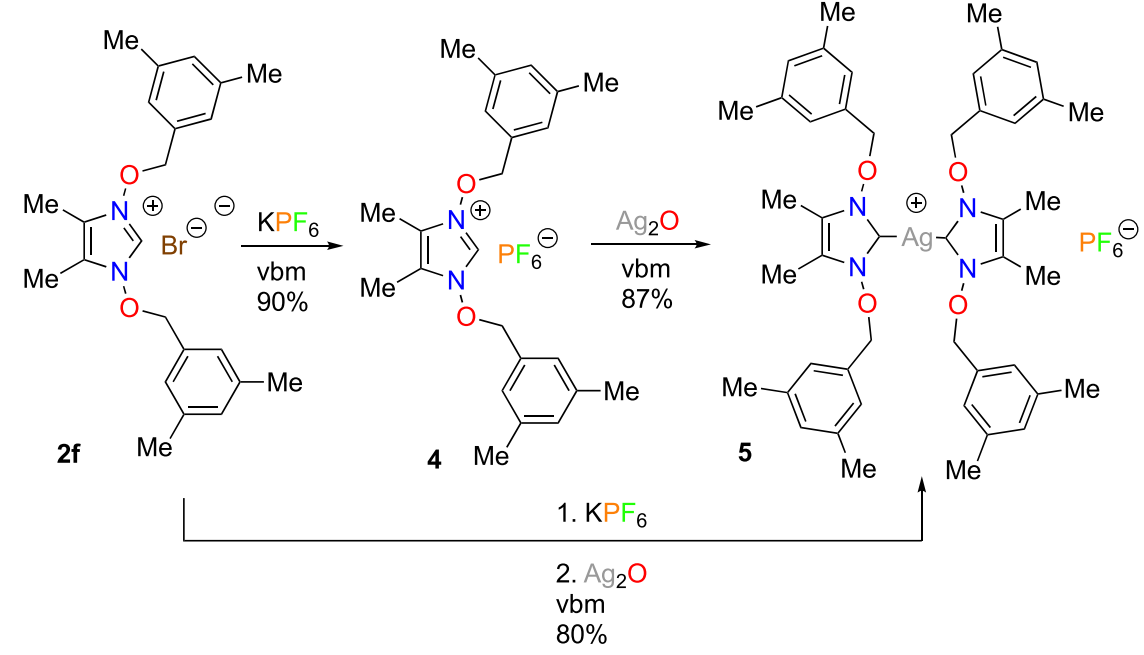

Scheme 3. Synthesis of $\left[\mathrm{Ag}(\mathrm{NOHC})_{2}\right] \mathrm{PF}_{6}$-complex $\mathbf{5}$.

a)

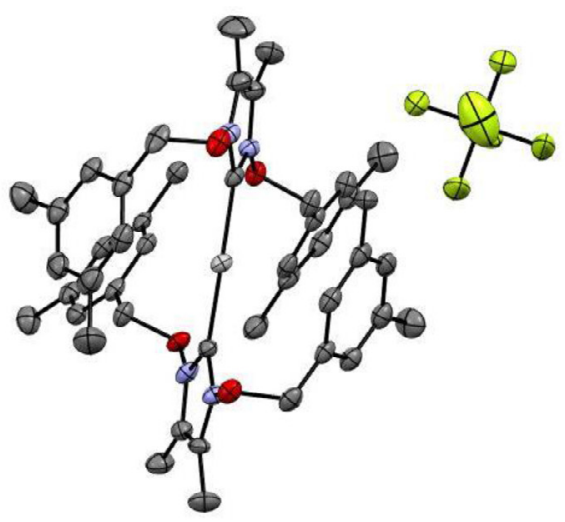

b)

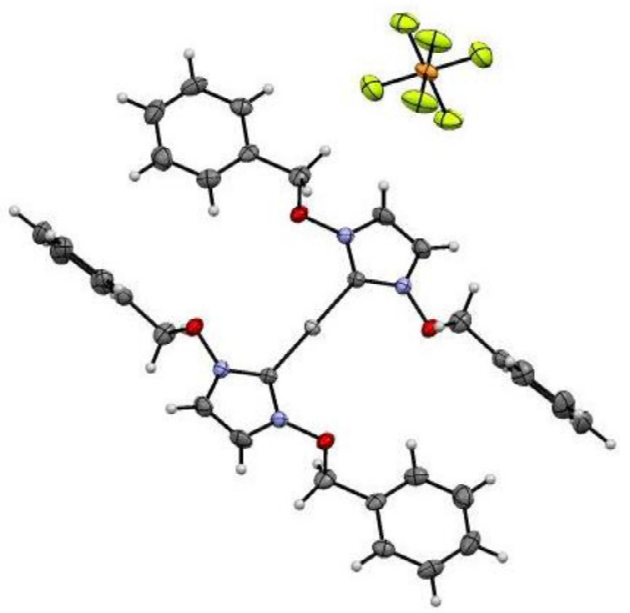

Fig. 1. ORTEPs (at 50\% probability level) of compounds (a) 5, (b) 6 (from ref [47]). Hydrogen atoms are omitted for clarity.

observation is in agreement with reports and reviews from the literature [8,9,61]. Interestingly, silver complex 6 exhibits a linear arrangement of the two carbene ligands and the silver atom (angle $\mathrm{C}-\mathrm{Ag}-\mathrm{C}: 180^{\circ}$ ), while in complex $\mathbf{5}$ the $\mathrm{C}-\mathrm{Ag}-\mathrm{C}$ arrangement presents a distortion with an angle of $168^{\circ}$. Furthermore, the two molecules of NOHCs in complex 6 lie essentially in the same plane (angle of $5.4^{\circ}$ ). In sharp contrast, a twist of $31.5^{\circ}$ is observed between the NOHCs molecules in 5. Finally, the torsion angles between the NOHCs and the four benzyl substituents (angle $\mathrm{N}-\mathrm{O}-\mathrm{CH}_{2}$-aryl) are quite different in each molecule: $159.1^{\circ}, 159.1^{\circ}$, $178.5^{\circ}, 178.5^{\circ}$ in 7 , confirming that the benzyl substituents are pointing away from the center of the complex. In $\mathbf{5}$, among these angles $\left(170.5^{\circ}, 171.9^{\circ}, 64.2^{\circ}, 67.1^{\circ}\right)$ two of them have similar values as the ones in $\mathbf{6}$ (benzyl pointing away) while two are much smaller with benzyl substituent pointing more towards the $\mathrm{C}-\mathrm{Ag}-\mathrm{C}$ bonds. Most probably, methyl groups present on the NOHC frameworks and on the benzyl substituents in $\mathbf{5}$ exert steric effects, inducing the various distortions observed in the structure compared to 6 .

The mechanoconversion of silver complexes into corresponding gold or copper complexes was tested using complex 3f. Transmetalation of $\mathbf{3 f}$ into a gold(I) complex was also performed in a ball mill by grinding a mixture of $\mathbf{3 f}$ and $\mathrm{AuCl} \bullet \mathrm{SMe}_{2}$ complex without any solvent (Scheme 4). The reaction was complete after $1 \mathrm{~h}$ and after typical work-up, the gold(I) complex 7 was obtained in $87 \%$ yield. The postulated structure was confirmed spectroscopically. Compared with its Ag precursor 3f, the diagnostic $C(2)$ signal of the carbenic center was high-field shifted and appeared at $157.9 \mathrm{ppm}$.

Analogously, Ag complex $3 f$ was converted into the copper complex 8 by grinding with $\mathrm{CuCl}$. In this case, the transmetalation was completed after $1 \mathrm{~h}$ and the pure product was isolated in $92 \%$ yield after filtration through a pad of celite layer (Scheme 4 ).

\subsection{Biological testing}

NHC metal complexes, including mechanosynthesized compounds, [27] have been tested in recent years on cancer cell lines and promising results were reported in some cases [15,16,56,62]. Because of their close structural similarity to NHCs, we investigated the possibility of the newly synthesized NOHC-stabilized metal complexes to display biological activities, all the more that, cytotoxic activities of alkylated imidazole $\mathrm{N}$-oxides were already reported [43]. This represents the first report of a cytotoxicity test performed on this family of potential metallodrugs.

The NOHC-metal complexes were tested against HCT116 colorectal cancer cell lines and the $\mathrm{IC}_{50}$ (half growth inhibition concentration) for the compounds that displayed the best activities in preliminary testing (see Supporting Information) was determined. 

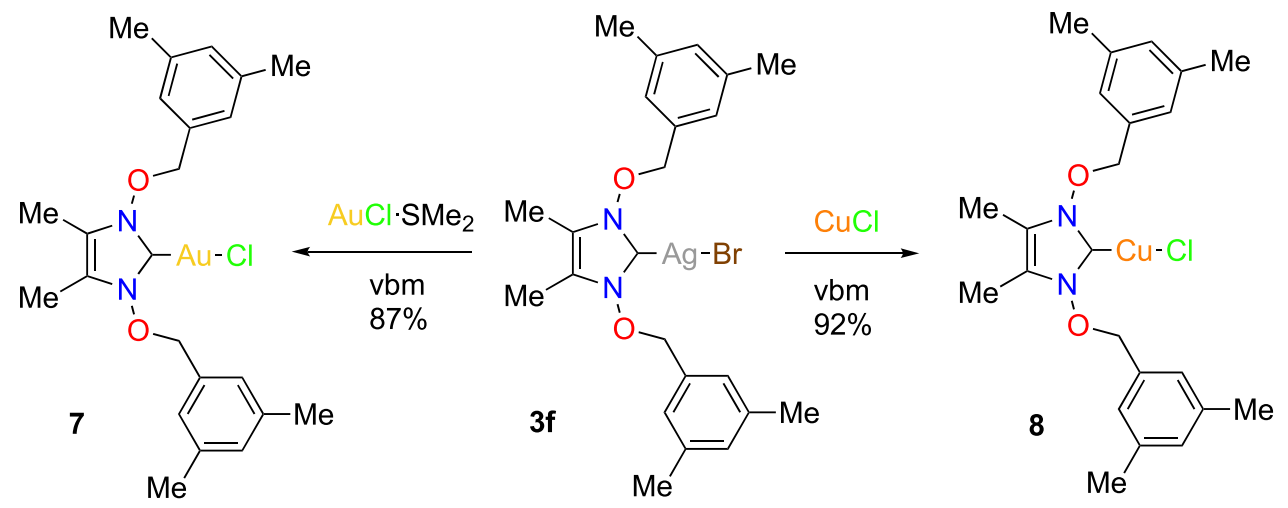

Scheme 4. Synthesis of NOHC-Au(I) complex 7 and NOHC-Cu(I) complex 8.

Doxorubicin was used as a positive control and displayed an $\mathrm{IC}_{50}$ value of $0.81 \mu \mathrm{M}$. First, we focused on complexes derived from imidazolium 2 f since corresponding silver complexes $\mathbf{3 f}$ and $\mathbf{5}$, gold complex $\mathbf{6}$ and copper complex $\mathbf{7}$ were available for comparison of their activities. Imidazolium $2 \mathbf{f}$ displayed an activity of $7.5 \mu \mathrm{M}$. The corresponding silver complex 3f did not show much better activity $(7.1 \mu \mathrm{M})$. To our disappointment, switching from silver to gold $\mathbf{7}$ or copper $\mathbf{8}$ did not result in a remarkable increase in the cytotoxicity of the tested compounds ( 8.70 and $7.8 \mu \mathrm{M}$, respectively). Subsequently, silver complexes $\mathbf{3 b} \mathbf{b}-\mathbf{e}$ and $\mathbf{3 g}$ were tested and it turned out that $\mathbf{3 c}$, 3d and $\mathbf{3 g}$ displayed such a low activity in preliminary cytotoxicity tests that further investigation of these compounds was not pursued. Interestingly, absence of methyl groups on the benzyloxy and keeping their presence on the NOHC backbone (complex 3e) resulted in decreased activity, compared to $\mathbf{3 f}$, with an $\mathrm{IC}_{50}$ value down to $8.65 \mu \mathrm{M}$. On the other hand, removing the methyl groups on the backbone and keeping one methyl at ortho position of the benzyloxy unit (complex $\mathbf{3 h}$ ) or two Me groups at meta position (complex $\mathbf{3 b}$ ) led to a slight increase of activity (5.6 and $4.68 \mu \mathrm{M}$, respectively). Finally, the cationic bis-NOHC silver complex 5 gave the best result with a cytotoxicity of $0.75 \mu \mathrm{M}$, similar to doxorubicin $(0.81 \mu \mathrm{M})$, and about ten times more potent than corresponding ligand $\mathbf{2 f}$ or mono-NOHC-silver complex 3f. The observed improvement of activity could be a consequence of an increased stability of $\mathbf{3 f}$, leading to a slow release of the silver ion [56].

\section{Experimental section}

\subsection{Synthesis of imidazolium bromides 2}

Imidazole $N$-oxide 1 (1.00 eq), benzyl bromide or its methylsubstituted derivative ( $2.2 \mathrm{eq})$, cesium carbonate $(0.5 \mathrm{eq})$ and $\mathrm{MeOH}$ (in the case of $\mathbf{2 b}, \mathbf{2 c}, \mathbf{2 f}, \mathbf{2}$ g: $0.5 \mu \mathrm{L} / \mathrm{mg}$ ) were placed in a $10 \mathrm{~mL}$ stainless steel grinding jar with one stainless steel ball (1 $\mathrm{cm}$ diameter). The jar was closed and subjected to grinding for $30 \mathrm{~min}$ in the vibratory ball mill operated at $25 \mathrm{~Hz}$. After that time, $\mathrm{CHCl}_{3}$ was added to the reaction mixture and the resulting solution was filtrated through a pad of celite. The solvent was evaporated and the precipitate was washed several times with $\mathrm{Et}_{2} \mathrm{O}$ to afford pure imidazolium bromide.

\subsection{Synthesis of NOHC-Ag(I)-complexes 3}

Imidazolium bromide 2 (1.00 eq) and silver oxide(I) (0.5 eq) were placed in a $10 \mathrm{~mL}$ stainless steel grinding jar with one stainless steel ball ( $1 \mathrm{~cm}$ diameter). The jar was closed and subjected to grinding for $30 \mathrm{~min}$ in the vibratory ball mill operating at $25 \mathrm{~Hz}$. After that time, $\mathrm{CHCl}_{3}$ was added to the reaction mixture and the resulting suspension was filtrated through a pad of celite. The solvent was evaporated and the obtained solid was washed several times with $\mathrm{Et}_{2} \mathrm{O}$ to afford pure NOHC-Ag(I)-complex.

\subsection{Synthesis of imidazolium hexafluorophosphate 4}

Imidazolium bromide 2 f $(69.7 \mathrm{mg}, 0.156 \mathrm{mmol}, 1.00 \mathrm{eq})$ and potassium hexafluorophosphate $(30.3 \mathrm{mg}, 0.165 \mathrm{mmol}, 1.05 \mathrm{eq})$ were placed in a $10 \mathrm{~mL}$ stainless steel grinding jar with one stainless steel ball $(1 \mathrm{~cm}$ diameter). The total mass of the reagents has been calculated so that the miling load equals $10.55 \mathrm{mg} / \mathrm{mL}$. The jar was closed and subjected to grinding for $30 \mathrm{~min}$ in the vibratory ball mill operated at $25 \mathrm{~Hz}$. After that time, $\mathrm{CHCl}_{3}$ was added to the reaction mixture and the resulting solution was filtrated through a pad of celite. The solvent was evaporated and the precipitate was washed several times with $\mathrm{Et}_{2} \mathrm{O}$ to afford pure 1,3-di[(3,5-dimethylbenzyl)oxy]-4,5-dimethyl$1 \mathrm{H}$-imidazol-3-ium hexafluorophosphate $4(71.8 \mathrm{mg}, 0.141 \mathrm{mmol}$, $90 \%$ ) as colourless crystals. Mp. $=147-148{ }^{\circ} \mathrm{C}$.

${ }^{1} \mathrm{H}$ NMR (500 MHz, $\left.\mathrm{CDCl}_{3}\right) \delta 8.84(\mathrm{~s}, 1 \mathrm{H}), 6.99(\mathrm{~s}, 2 \mathrm{H}), 6.96$ (s, 4H), $5.17(\mathrm{~s}, 4 \mathrm{H}), 2.26(\mathrm{~s}, 12 \mathrm{H}), 2.14(\mathrm{~s}, 6 \mathrm{H}) \mathrm{ppm} .{ }^{13} \mathrm{C}$ NMR $\left(126 \mathrm{MHz}, \mathrm{CDCl}_{3}\right) \delta 138.8,132.0,131.3,128.3,126.2,123.8,85.0$, 21.2, $7.2 \mathrm{ppm} .{ }^{31} \mathrm{P}$ NMR (202 $\left.\mathrm{MHz}, \mathrm{CDCl}_{3}\right) \delta-143.97$ (sept, $J=714.9 \mathrm{~Hz})$ ppm. ${ }^{19} \mathrm{~F} \mathrm{NMR}\left(470 \mathrm{MHz}, \mathrm{CDCl}_{3}\right) \delta-72.31$ (d, $J=714.2 \mathrm{~Hz}) \mathrm{ppm}$.

HRMS (ESI/TOF) m/z: calcd for $\mathrm{C}_{23} \mathrm{H}_{29} \mathrm{~N}_{2} \mathrm{O}_{2}$ : 365.2229 [M$\left.\mathrm{PF}_{6}{ }^{-}\right]^{+}$; found: 365.2225 .

IR $\left(\mathrm{cm}^{-1}\right): 3138 \mathrm{~m}, 2959 \mathrm{~m}, 1743 \mathrm{~s}, 1606 \mathrm{~m}, 1445 \mathrm{~m}, 1378 \mathrm{~m}$, $1211 \mathrm{~m}, 1077$ w, $896 \mathrm{~m}, 826 \mathrm{~s}, 724 \mathrm{~m}, 610 \mathrm{~m}, 557 \mathrm{~s}, 522 \mathrm{~m}$.

Anal. Calcd for $\mathrm{C}_{23} \mathrm{H}_{29} \mathrm{~N}_{2} \mathrm{O}_{2} \mathrm{~F}_{6} \mathrm{P}$ : C, 54.12; $\mathrm{H}, 5.73 ; \mathrm{N}, 5.49$. Found: C, 54.12; H, 5.65; N, 5.46.

\subsection{Synthesis of $\left[\mathrm{Ag}(\mathrm{NOHC})_{2}\right] \mathrm{PF}_{6}$-complex 5}

Method A: 1,3-Di[(3,5-dimethylbenzyl)oxy]-4,5-dimethyl-1Himidazol-3-ium hexafluorophosphate $4(51.2 \mathrm{mg}, 0.100 \mathrm{mmol}$, $1.00 \mathrm{eq})$ and silver oxide $(48.8 \mathrm{mg}, 0.211 \mathrm{mmol}, 2.10 \mathrm{eq})$ were placed in a $10 \mathrm{~mL}$ stainless steel grinding jar with one stainless steel ball ( $10 \mathrm{~mm}$ diameter). The total mass of the reagents was calculated so that the milling load equals $10.55 \mathrm{mg} / \mathrm{mL}$. The jar was closed and subjected to grinding for $4 \mathrm{~h}$ in the vibratory ball mill operated at $25 \mathrm{~Hz}$. The black powder was recovered with dichloromethane and the suspension was filtrated through a pad of celite. The filtrate was concentrated under vacuum to afford 1,3$\operatorname{di}\{[(3,5$-dimethylbenzyl)oxy $]$-4,5-dimethylimidazolyl-2-ene $]$ silver hexafluorophosphate 5 (42.8 $\mathrm{mg}, 0.043 \mathrm{mmol}, 87 \%)$ as a white solid.

Method B: 1,3-Di[(3,5-dimethylbenzyl)oxy]-4,5-dimethyl-1Himidazol-3-ium bromide 2 f $(39.9 \mathrm{mg}, 0.090 \mathrm{mmol}, 1.00 \mathrm{eq})$ and 


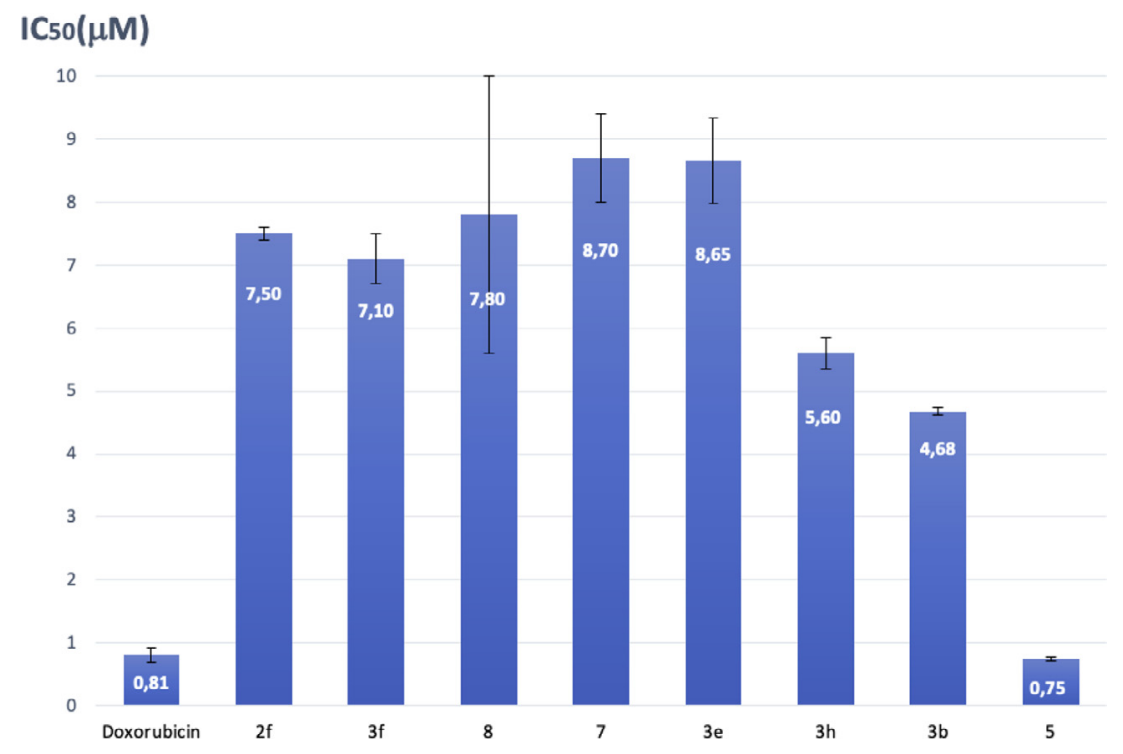

Fig. 2. $\mathrm{IC}_{50}(\mu \mathrm{M})$ values against HCT116 carcinoma cells.

potassium hexafluorophosphate $(16.5 \mathrm{mg}, 0.090 \mathrm{mmol}, 1.00 \mathrm{eq})$ were placed in a $10 \mathrm{~mL}$ stainless steel grinding jar with one stainless steel ball (10 mm diameter). The jar was closed and subjected to grinding for $30 \mathrm{~min}$ in the vibratory ball mill operated at $25 \mathrm{~Hz}$. Afterwards, silver oxide $(43.6 \mathrm{mg}, 0.188 \mathrm{mmol}$, $2.10 \mathrm{eq})$ was added. The total mass of the reagents was calculated so that the milling load equals $19.2 \mathrm{mg} / \mathrm{mL}$. The jar was closed and subjected to grinding for 1 hour. The black powder was recovered with dichloromethane and filtrated through a pad of celite. The filtrate was concentrated under vacuum to afford 1,3di[(3,5-dimethylbenzyl)oxy]-4,5-dimethylimidazolyl-2-ene]silver hexafluorophosphate 5 (35.1 $\mathrm{mg}, 0.0358 \mathrm{mmol}, 80 \%)$ as a white solid. Mp. $=197-198{ }^{\circ} \mathrm{C}$.

${ }^{1} \mathrm{H}$ NMR $\left(500 \mathrm{MHz}, \mathrm{CDCl}_{3}\right) \delta 6.93(\mathrm{~s}, 12 \mathrm{H}), 5.06(\mathrm{~s}, 8 \mathrm{H}), 2.20$, $2.15(2 \mathrm{xs}, 36 \mathrm{H}) \mathrm{ppm} .{ }^{13} \mathrm{C}$ NMR $\left(126 \mathrm{MHz}, \mathrm{CDCl}_{3}\right) \delta$ 138.7, 132.6, 131.5, 128.0, 121.7, 82.9, 21.2, 7.8 ppm. ${ }^{31} \mathrm{P}$ NMR (202 MHz, $\left.\mathrm{CDCl}_{3}\right)$ $\delta-144.08$ (sept, $J=707.9 \mathrm{~Hz}$ ) ppm. ${ }^{19} \mathrm{~F}$ NMR $\left(470 \mathrm{MHz}, \mathrm{CDCl}_{3}\right) \delta$ $-73.70(\mathrm{~d}, J=718.7 \mathrm{~Hz}) \mathrm{ppm}$.

HRMS (ESI/TOF) m/z: calcd for $\mathrm{C}_{46} \mathrm{H}_{56} \mathrm{~N}_{4} \mathrm{O}_{4} \mathrm{Ag}$ : 835.3352 [M$\left.\mathrm{PF}_{6}{ }^{-}\right]^{+}$; found: 835.3366 .

IR $\left(\mathrm{cm}^{-1}\right)$ : $3013 \mathrm{~m}, 2966 \mathrm{~m}, 1737 \mathrm{~s}, 1605 \mathrm{w}, 1442 \mathrm{~m}, 1366 \mathrm{~s}$, 1229 m, 1214 w, 1200 m, 1074 w, 945 m, 835 s, 715 m, 680 m, $554 \mathrm{~m}, 522 \mathrm{~m}$.

Anal. Calcd for $\mathrm{C}_{46} \mathrm{H}_{56} \mathrm{AgN}_{4} \mathrm{O}_{4} \mathrm{~F}_{6} \mathrm{P}: \mathrm{C}, 56.27 ; \mathrm{H}, 5.75 ; \mathrm{N}, 5.71$. Found: C, 56.25; H, 5.83; N, 5.95.

\subsection{Synthesis of NOHC-Au(I)-complex 7}

Imidazolium silver bromide $\mathbf{3 f}(61.0 \mathrm{mg}, 0.110 \mathrm{mmol}, 1.00 \mathrm{eq})$ and chloro(dimethylsulfide)gold(I) $(39.0 \mathrm{mg}, 0.133 \mathrm{mmol}, 1.20 \mathrm{eq}$ ) were placed in a $10 \mathrm{~mL}$ stainless steel grinding jar with one stainless steel ball ( $1 \mathrm{~cm}$ diameter). The total mass of the reagents has been calculated so that the miling load equals $10.55 \mathrm{mg} / \mathrm{mL}$. The jar was closed and subjected to grinding for $1 \mathrm{~h}$ in the vibratory ball mill operated at $25 \mathrm{~Hz}$. After that time, $\mathrm{CHCl}_{3}$ was added to the reaction mixture and the resulting solution was filtrated through a pad of celite. The solvent was evaporated, and the precipitate was washed several times with $\mathrm{Et}_{2} \mathrm{O}$ to afford pure 1,3-di\{[(3,5-dimethylbenzyl)oxy $]$-4,5-dimethylimidazol-2ylidene)gold chloride $7(57.2 \mathrm{mg}, 0.096 \mathrm{mmol}, 87 \%)$ as colourless crystals. Mp. $=217-218{ }^{\circ} \mathrm{C}$.
${ }^{1} \mathrm{H}$ NMR (500 MHz, $\left.\mathrm{CDCl}_{3}\right) \delta 7.08-7.01(\mathrm{~m}, 6 \mathrm{H}), 5.29(\mathrm{~s}, 4 \mathrm{H})$, $2.32(\mathrm{~s}, 12 \mathrm{H}), 1.92(\mathrm{~s}, 6 \mathrm{H}) \mathrm{ppm} .{ }^{13} \mathrm{C}$ NMR $\left(126 \mathrm{MHz}, \mathrm{CDCl}_{3}\right) \delta 157.9$, 138.6, 132.5, 131.6, 128.2, 120.8, 82.7, 21.3, $7.8 \mathrm{ppm}$.

HRMS (ESI/TOF): $m / z$ calcd for $\mathrm{C}_{23} \mathrm{H}_{28} \mathrm{~N}_{2} \mathrm{O}_{2} \mathrm{Au}_{1} \mathrm{Cl}_{1} \mathrm{Na}_{1}: 619.1406$ [M+Na+ ]; found: $619.1403, \mathrm{~m} / z$ calcd for $\mathrm{C}_{23} \mathrm{H}_{28} \mathrm{~N}_{2} \mathrm{O}_{2} \mathrm{Au}_{1}: 561.1816$ [M-Cl] $]^{+}$; found: $561.1818, \mathrm{~m} / z$ calcd for $\mathrm{C}_{46} \mathrm{H}_{56} \mathrm{~N}_{4} \mathrm{O}_{4} \mathrm{Au}_{1}: 925.3967$ $\left[2 \mathrm{M}-A u C l_{2}\right]^{+}$; found: 952.3972 .

IR $\left(\mathrm{cm}^{-1}\right)$ : $2919 \mathrm{~m}, 1769 \mathrm{~m}, 1608 \mathrm{~m}, 1468 \mathrm{~m}, 1386 \mathrm{~m}, 1240 \mathrm{~m}$, 1167 m, 1077 m, 943 s, 919 m, 849 s, 709 m, 674 s.

Anal. Calcd for $\mathrm{C}_{23} \mathrm{H}_{28} \mathrm{AuClN}_{2} \mathrm{O}_{2} \bullet 0.2 \mathrm{CH}_{2} \mathrm{Cl}_{2}$ : C, 45.39; $\mathrm{H}, 4.66$; N, 4.56. Found: C, 45.17; H, 4.94; N, 4.61.

\subsection{Synthesis of NOHC-Cu(I)-complex 8}

Imidazolium silver bromide $\mathbf{3 f}(55.2 \mathrm{mg}, 0.100 \mathrm{mmol}, 1.00 \mathrm{eq})$ and copper(I) chloride (14.8 $\mathrm{mg}, 0.150 \mathrm{mmol}, 1.50 \mathrm{eq})$ were placed in a $10 \mathrm{~mL}$ stainless steel grinding jar equipped with one stainless steel ball ( $1 \mathrm{~cm}$ diameter). The total mass of the reagents has been calculated so that the miling load equals $7.39 \mathrm{mg} / \mathrm{mL}$. The jar was closed and subjected to grinding for $1 \mathrm{~h}$ in the vibratory ball mill operated at $25 \mathrm{~Hz}$. After that time, $\mathrm{CHCl}_{3}$ was added to the reaction mixture and the resulting solution was filtrated through a pad of celite. The solvent was evaporated, and the obtained solid was washed several times with $\mathrm{Et}_{2} \mathrm{O}$ to afford pure 1,3-di\{[(3,5-dimethylbenzyl)oxy]-4,5-dimethylimidazol-2ylidene copper chloride 8 (42.6 $\mathrm{mg}, 0.092 \mathrm{mmol}, 92 \%)$ as a pale yellow powder. $\mathrm{Mp} .=175-176{ }^{\circ} \mathrm{C}$.

${ }^{1} \mathrm{H}$ NMR $\left(500 \mathrm{MHz}, \mathrm{CDCl}_{3}\right) \delta 7.02(\mathrm{~s}, 6 \mathrm{H}), 5.18(\mathrm{~s}, 4 \mathrm{H}), 2.32(\mathrm{~s}$, $12 \mathrm{H}), 1.92(\mathrm{~s}, 6 \mathrm{H}) \mathrm{ppm} .{ }^{13} \mathrm{C}$ NMR $\left(126 \mathrm{MHz}, \mathrm{CDCl}_{3}\right) \delta 138.7,132.6$, 131.5, 128.1, 120.7, 82.9, 21.3, 7.6 ppm.

HRMS (ESI/TOF): $m / z$ calcd for $\mathrm{C}_{23} \mathrm{H}_{28} \mathrm{~N}_{2} \mathrm{O}_{2} \mathrm{Cu}_{1} \mathrm{Cl}_{1} \mathrm{Na}_{1}: 485.1033$ [M+Na+ ]; found: $485.1035, \mathrm{~m} / z$ calcd for $\mathrm{C}_{23} \mathrm{H}_{28} \mathrm{~N}_{2} \mathrm{O}_{2} \mathrm{Cu}_{1}: 427.1447$ [M-Cl] $]^{+}$; found: $427.1447, \mathrm{~m} / z$ calcd for $\mathrm{C}_{46} \mathrm{H}_{56} \mathrm{~N}_{4} \mathrm{O}_{4} \mathrm{Cu}_{1}: 791.3598$ [2M-CuCl$]^{+}$; found: 791.3605 .

IR $\left(\mathrm{cm}^{-1}\right)$ : $2916 \mathrm{~m}, 1757 \mathrm{~m}, 1643 \mathrm{~m}, 1608 \mathrm{~m}, 1456 \mathrm{~m}, 1380 \mathrm{~m}$, $1167 \mathrm{~m}, 1077 \mathrm{~m}, 1036 \mathrm{~m}, 942 \mathrm{~m}, 893 \mathrm{~m}, 849 \mathrm{~s}, 683 \mathrm{~s}, 665 \mathrm{~m}$.

Anal. Calcd for $\mathrm{C}_{23} \mathrm{H}_{28} \mathrm{ClCuN}_{2} \mathrm{O}_{2} \bullet 0.2 \mathrm{CH}_{2} \mathrm{Cl}_{2}$ : C, 58.26; $\mathrm{H}, 5.98$; $\mathrm{N}$, 5.87. Found: C, 58.26; H, 5.99; N, 6.00.

\section{Conclusions}

A multi-step mechanosynthesis of 1,3-di(benzyloxy)imidazol-2ylidene metal complexes is described. Starting $N$-hydroxy imida- 
zole $\mathrm{N}$-oxides were prepared from respective substrates by reaction in a vibratory ball-mill. This initial step was followed by $O$-benzylation, and subsequent metalation which were also performed in a vbm. In these three steps, mechanical milling provided an essentially solvent-free procedure with considerable reduction of the reaction times. These protocols opened the route to an efficient preparation of new 1,3-di(benzyloxy)imidazol-2ylidene silver, and gold and copper complexes. Two latter representatives were obtained via mechanotransmetalation approach. All new complexes were characterized spectroscopically and two of them were subjected to single crystal X-ray analysis. In extension of the study, new NHOCs complexes were evaluated for their cytotoxic activity against the HCT116 colorectal cancer cell line. Homoleptic silver complex $\mathbf{5}$ displayed remarkably high activity, similar to the known doxorubicin. These reported results demonstrate once more that mechanochemistry can be exploited as a welladapted method for the preparation of NOHCs and corresponding metallic complexes. Furthermore, this work supports the validity of a strategical approach to discover new metallodrugs based on the principles of medicinal mechanochemistry [27,63-65].

Fig. 2

\section{Declaration of Competing Interest}

The authors declare that they have no known competing financial interests or personal relationships that could have appeared to influence the work reported in this paper.

\section{Acknowledgments}

The authors thank for financial support the National Science Center (Cracow, Poland) within the Projects: OPUS-13 Grant no. 2017/25/B/ST4/02684 (A.W.) and BEETHOVEN-2 Grant no. 2016/23/G/ST5/04115 (G.M.), the University of Montpellier and the CNRS. G.M. thanks Professor Peter R. Schreiner (Giessen) for valuable discussion on the chemistry of nucleophilic heterocyclic carbenes (NOHC type).

\section{References}

[1] F. Gomollón-Bel, Chem. Int. 41 (2019) 12.

[2] J.L. Howard, Q. Cao, D.L. Browne, Chem. Sci. 9 (2018) 3080

[3] T. Friščić, C. Mottillo, H.M. Titi, Angew. Chem., Int. Ed. 59 (2020) 1018.

[4] A.L. Garay, A. Pichon, S.L. James, Chem. Soc. Rev. 36 (2007) 846.

[5] N.R. Rightmire, T.P. Hanusa, Dalton Trans. 45 (2016) 2352.

[6] A.A. Geciauskaite, F. García, Beilstein J. Org. Chem. 13 (2017) 2068.

[7] A. Beillard, X. Bantreil, T.-X. Métro, J. Martinez, F. Lamaty, Chem. Rev. 119 (2019) 7529.

[8] A.J. Arduengo, R.L. III; Harlow, M. Kline, J. Am. Chem. Soc. 113 (1991) 361.

[9] A.J. Arduengo III, H.V.R. Dias, R.L. Harlow, M Kline, J. Am. Chem. Soc. 114 (1992) 5530

[10] S. Diez-Gonzalez, N. Marion, S.P. Nolan, Chem. Rev. 109 (2009) 3612.

[11] E. Colacino, J. Martinez, F. Lamaty, Coord. Chem. Rev. 251 (2007) 726

[12] L.-.A. Schaper, S.J. Hock, W.A. Herrmann, F.E. Kuehn, Angew. Chem., Int. Ed. 52 (2013) 270

[13] D.M. Flanigan, F. Romanov-Michailidis, N.A. White, T. Rovis, Chem. Rev. 115 (2015) 9307.

[14] R. Visbal, M.C. Gimeno, Chem. Soc. Rev 43 (2014) 3551.

[15] S.Y. Hussaini, R.A. Haque, M.R. Razali, J. Organomet. Chem. 882 (2019) 96.

[16] M. Mora, M.C. Gimeno, R. Visbal, Chem. Soc. Rev. 48 (2019) 447.

[17] C.J. Adams, M. Lusi, E.M. Mutambi, A. Guy Orpen, Chem. Commun. 51 (2015) 9632.

[18] A. Beillard, E. Golliard, V. Gillet, X. Bantreil, T.-.X. Métro, J. Martinez, F. Lamaty, Chem. Eur. J. 21 (2015) 17614
[19] A. Beillard, X. Bantreil, T.-.X. Métro, J. Martinez, F. Lamaty, Dalton Trans 45 (2016) 17859.

[20] C.J. Adams, M. Lusi, E.M. Mutambi, A.G. Orpen, Cryst. Growth Des. 17 (2017) 3151.

[21] A. Beillard, X. Bantreil, T.-.X. Métro, J. Martinez, F. Lamaty, New J. Chem. 41 (2017) 1057.

[22] A. Beillard, T.-.X. Métro, X. Bantreil, J. Martinez, F. Lamaty, Chem. Sci. 8 (2017) 1086.

[23] A. Beillard, X. Bantreil, T.-.X. Métro, J. Martinez, F. Lamaty, Green Chem. 20 (2018) 964

[24] I.E. Chikunov, G.S. Ranny, A.V. Astakhov, V.A. Tafeenko, V.M. Chernyshev, Russ. Chem. Bull. 67 (2018) 2003.

[25] N. Mukherjee, A. Marczyk, G. Szczepaniak, A. Sytniczuk, A. Kajetanowicz, K. Grela, ChemCatChem 11 (2019) 5362

[26] R.J. Allenbaugh, J.R. Zachary, A.N. Underwood, J.D. Bryson, J.R. Williams, A. Shaw, Inorg. Chem. Commun. 111 (2020) 107622.

[27] A. Beillard, F. Quintin, J. Gatignol, P. Retailleau, J.-.L. Renaud, S. Gaillard, T.-.X. Métro, F. Lamaty, X. Bantreil, Dalton Trans 49 (2020) 12592.

[28] S. De, F. Joo, H. Horvath, A. Udvardy, C.E. Czegeni, J. Organomet. Chem. 918 (2020) 121308

[29] G. Pisano, C.S.J. Cazin, Green Chem 22 (2020) 5253

[30] F. Quintin, J. Pinaud, F. Lamaty, X. Bantreil, Organometallics 39 (2020) 636.

[31] A. Beillard, T.-X. Métro, X. Bantreil, J. Martinez, F. Lamaty, Eur. J. Org. Chem. 2017 (2017) 4642.

[32] La Parola, G. Gazz, Chim. Ital. 75 (1945) 216.

[33] J.B. Wright, J. Org. Chem. 29 (1964) 1620.

[34] K. Bodendorf, H. Towliati, Arch. Pharm. (Weinheim) 298 (1965) 293.

[35] P. Franchetti, M. Grifantini, C. Lucarelli, M.L. Stein, Farmaco, Ed. Sci. 27 (1972) 46.

[36] C. Froschauer, H.K. Weber, T. Roeder, H. Sixta, G. Laus, B. Lendl, H. Schottenberger, Lenzinger Ber 91 (2013) 30

[37] M. Jochriem, C.G. Kirchler, G. Laus, K. Wurst, H. Kopacka, T. Mueller, H. Schottenberger, Z. Naturforsch., B: J. Chem. Sci. 72 (2017) 617.

[38] F. Meischl, M. Harder, C.G. Kirchler, J. Kremser, C.W. Huck, G.K. Bonn, M. Rainer, J. Mol. Liq. 289 (2019) 111157.

[39] M. Zeeshan, V. Nozari, S. Keskin, A. Uzun, Ind. Eng. Chem. Res. 58 (2019) 14124.

[40] S. Huber, M. Harder, K. Funck, K. Erharter, M. Popp, G.K. Bonn, M. Rainer, Separations 7 (2020) 45

[41] M. Kreidl, M. Harder, M. Rainer, G.K. Bonn, Anal. Methods 12 (2020) 4377.

[42] D. Bhawna; Dhingra, A. Pandey, S. Pandey, J. Photochem. Photobiol., A 406 (2021) 112991

[43] G. Mlostoń, M. Celeda, W. Poper, M. Kowalczyk, K. Gach-Janczak, A. Janecka, M. Jasiński, Materials (Basel) 13 (2020) 4190.

[44] G. Laus, A. Schwaerzler, P. Schuster, G. Bentivoglio, M. Hummel, K. Wurst, V. Kahlenberg, T. Loerting, J. Schuetz, P. Peringer, G. Bonn, G. Nauer, H. Schottenberger, Z. Naturforsch., B: Chem. Sci. 62 (2007) 295.

[45] A.K. Guha, S. Sarmah, A.K. Phukan, Dalton Trans 39 (2010) 7374

[46] M. Freindorf, D. Cremer, E. Kraka, Mol. Phys. 116 (2018) 611.

[47] G. Laus, K. Wurst, V. Kahlenberg, H. Kopacka, C. Kreutz, H. Schottenberger, Z Naturforsch., B: J. Chem. Sci. 65 (2010) 776.

[48] B. Rietzler, G. Laus, V. Kahlenberg, H. Schottenberger, Acta Crystallogr., Sect. E: Crystallogr. Commun. 71 (2015) m251.

[49] S. Bartz, B. Blumenroeder, A. Kern, J. Fleckenstein, S. Frohnapfel, J. Schatz, A. Wagner, Z. Naturforsch., B: J. Chem. Sci. 64 (2009) 629.

[50] T. Brendgen, T. Fahlbusch, M. Frank, D.T. Schuehle, M. Sessler, J. Schatz, Adv. Synth. Catal. 351 (2009) 303

[51] M.K. Dudek, J. Śniechowska, A. Wróblewska, S. Kaźmierski, M.J. Potrzebowski, Chem. - Eur. J. 26 (2020) 13264.

[52] A. Wróblewska, J. Śniechowska, S. Kaźmierski, E. Wielgus, G.D. Bujacz, G. Mlostoń, A. Chworos, J. Suwara, M.J. Potrzebowski, Pharmaceutics 12 (2020) 359.

[53] G. Mlostoń, M. Celeda, K. Urbaniak, M. Jasiński, V. Bakhonsky, P.R. Schreiner, H. Heimgartner, Beilstein J. Org. Chem. 15 (2019) 497.

[54] G. Mlostoń, M. Celeda, M. Jasiński, K. Urbaniak, P.J. Boratyński, P.R. Schreiner, H. Heimgartner, Molecules 24 (2019) 4398.

[55] G. Mlostoń, M. Jasiński, A. Wróblewska, H. Heimgartner, Curr. Org. Chem. 20 (2016) 1359.

[56] N.A. Johnson, M.R. Southerland, W.J. Youngs, Molecules 22 (2017) 1263/1.

[57] G.A. Bowmaker, Chem. Commun. 49 (2013) 334.

[58] V. Porte, M. Thioloy, T. Pigoux, T.-.X. Métro, J. Martinez, F. Lamaty, Eur. J. Org. Chem. (2016) 3505.

[59] D. Tan, F. García, Chem. Soc. Rev. 48 (2019) 2274.

[60] H.M.J. Wang, I.J.B Lin, Organometallics 17 (1998) 972.

[61] F.E. Hahn, M.C. Jahnke, Angew. Chem., Int. Ed. 47 (2008) 3122

[62] Ott, I. In Advances in Inorganic Chemistry; Sadler, P. J., van Eldik, R., Eds.; Academic Press: 2020; Vol. 75, p 121.

[63] D. Tan, L. Loots, T. Friščić, Chem. Commun. 52 (2016) 7760.

[64] A.S. McCalmont, A. Ruiz, M.C. Lagunas, W.T. Al-Jamal, D.E. Crawford, ACS Sustainable Chem. Eng. 8 (2020) 15243.

[65] P. Milbeo, F. Quintin, L. Moulat, C. Didierjean, J. Martinez, X. Bantreil, M. Calmès, F. Lamaty, Tetrahedron Lett. 63 (2021) 152706. 